\title{
Tunus'ta İstikrarın Formülü: Üç Sacayağı
}

\author{
Yusuf YAMAN
}

\section{Öz}

Yasemin Devrimi, Tunus'un ötesinde etkiler ortaya koymuş, Arap Baharı diye adlandırılan süreci tetiklemiştir. Süreci yoğun şekilde yaşayan Libya, Mısır ve Suriye gibi ülkelerden farklı olarak Tunus, "Yasemin Devrimi" denilen bu başkaldırıyı toplumdaki dinamikleri önemli oranda uzlaştıran yeni bir anayasayla sonuçlandırmıştır. Bu uzlaşı sürecinin kökeninde ne var? Diğer Arap Ülkelerinde ortaya çıkan karşı devrim(Mısır), iç savaş(Suriye) ve kaos(Libya) ortamına rağmen Tunus'ta istikrarın arkasında üç sacayağının olduğunu göreceğiz. Bunlar: Demokrasinin vazgeçilmezlerinden çok partili hayat, sivil toplum kuruluşları ve de Raşid Gannuşi’nin siyasi dehası olduğu düşünülmektedir. Bu çerçevede şekillenen çalışmamız Tunus'ta varılan sentezin, diğer ülkeler için bir model olma potansiyelini de gündeme getirecektir.

Anahtar Kelimeler: Tunus, Yasemin Devrimi, Arap Baharı, Sivil Toplum Kuruluşu, Raşid Gannuşi.

\section{Stability Formula in Tunusia: The Three Trivets}

\begin{abstract}
The Jasmine Revolution, has brought up influences beyond Tunisia, triggering the continuum called the Arab Spring. Tunisia, unlike countries such as Libya, Egypt and Syria where the process was intensive, the so called "Jasmine Revolution" ended up with a new constitution that reconciles the dynamics of the society in a significant way. What is in the origin of this reconciliation process? Despite the counter-revolution (Egypt), civil war (Syria) and chaos (Libya) that have emerged in other Arab countries, we will see that there are three trivets behind the stability in Tunisia. Multiparty life from indispensable democracy, nongovernmental organizations and Raşid Ghannouchi's political genius are thought to be more important. Our shaped work in this context, the synthesis reached in Tunisia will be the potential model for other countries.
\end{abstract}

Keywords: Tunisia, Jasmine Revolution, Arab Spring, Civil Society Organization, Raşid Ghannouch

\footnotetext{
${ }^{1}$ Doktora öğrencisi, Marmara Üniversitesi, Sosyal Bilimler Enstitüsü, Din Sosyoloji, yyamanankara@gmail.com Bu makale URKUND programı yardımıyla intihale karşı kontrol edilmiştir.
} 


\section{Giriş}

Yasemin Devrimi sonrası oluşan iktidar boşluğunun en önemli alternatifi olan hatta iktidara geleceğine kesin gözüyle bakılan, Gannuşi yönetimindeki İslamcı Nahda Partisi'nin varlığ 1 laik kesim ve batı için kaygı konusu olmuştur. Habib Burgiba ve Bin Ali yönetiminin adaletten uzak tutumu Nahda'nın başarısına giden yolu açmıştır.

17 Aralık 2010 tarihinde Muhammed Buazizi'nin kendisini yakmasıyla fitillenen olaylar, otoriter yönetimin devrilmesini sağlarken, yeni yönetimin serbest seçimlerle belirlenmesi seçeneğini Tunus'un gündemine getirmiştir. Seçimlerde birinci parti olarak çıkmayı başaran İslamcı Nahda, yeni dönemin inşasına yönelirken, aynı zamanda Feldman'ın, Arap ve İslam dünyasındaki yönetimlerin yarattığı hoşnutsuzluğu dikkate alarak, serbest seçimlerin İslamc1 partilerin başarısıyla sonuçlanacağı yönündeki öngörüsünü ilk anda doğrulamıştır. Feldman'a göre, serbest seçim ortamlarında, İslamcılar hükümete gelecekte başarısız olacakları vakte kadar da muhtemelen halkın oyunu almaya devam edecekler. Arap ve İslam dünyasındaki yönetimlerin anti demokratik tutumları, İslamcıları cazip bir aktör haline getirmiştir. Tüm gücü elinde bulunduran yöneticilerin adaletsiz yönetimleri, doğal olarak bir alternatif arayışını doğurmuştu.(Feldman2013:198). Bu alternatif arayışının temsilcisi olarak belli bir mücadele birikimi üzerinden şekillenmiş İslamcı hareket Arap Baharı sürecinde iktidarın kuvvetli adayı olarak öne geçmiştir. Nahda, bu sürecin Tunus’ta öne çıkan bir ayağıydı.

Bu tarz dönüşümlere, çeşitli gel - gitler içeren kaotik süreçlerin eşlik etmesi genellikle beklenen bir gelişmedir. Bununla birlikte Tunus'taki dönüşüm nispeten kolay ve hızlı gerçekleşmiştir. Otoriter rejimlerin akabinde ortaya çıkacak yeni düzenler için bir değerlendirmede belirtildiği üzere; "Demokratik geçişler nadiren pürüzsüzdür. Demokrasi, bu geçişler için iç ve dış engeller göz önüne alındığında, özellikle baskı ve otokrasi öyküsü olan ülkelerde konsolide etmek için uzun yıllara ihtiyaç duyar. Siyasi analistler ve politikacilar Tunus'u, demokratik geçişin diktatörlük sonrası nispeten düzgün bir şekilde gerçekleştiği bir ülke olarak lanse etmişlerdir." "2. Yasemin Devrimi sürecini özetler nitelikte olan bu tespit Tunus'taki yumuşak dönüşümü işaret etmesi bakımından kayda değerdir.

Misır, Libya, Suriye, Bahreyn, Ürdün, Yemen gibi, Arap baharı sürecinden geçmiş, ancak netice itibariyle otoriter rejimlerin, bazen başka kişiler eliyle de olsa, muhafaza edildiği ülkelerin aksine demokrasi sürecini yürütme başarısını göstermiş Tunus, özgünlükleri bakımından incelenmeyi hak eden bir örnektir. Diğer tüm ülkelerde “Arap Baharı” kışa dönmüşken,

${ }^{2}$ http://studies.aljazeera.net/en/rports/2015/03/

201531692158762938.html, Erişim tarihi:

$16 / 12 / 2017$ 
Tunus'ta başarının yakalanmış olmasını anlamak bir gereklilik olarak karşımıza çıkmaktadir.

$\mathrm{Bu}$ minvalden hareketle, çalışmada, istikrarlı bir siyasal seyir izleyen ve toplumsal konsensüsle süreci ilerleten Tunus'ta başarının Saikleri üzerinde durulacak, "tarihsel sosyoloji"’3 çerçevesinde Tunus'u kendi iç dinamikleriyle ele alınacaktır. Tunus toplumunun çeşitli dönemleri arasında karşılaştırmaya imkan sunan literatür taraması ile yığın olayları ve bunların oluşturduğu yığınları inceleme firsatı veren istatistiki metotlar(Arslantürk 2014: 43-44) araştırmada kullanılacaktır. Arap baharı süreci, Tunus özelinde incelenirken, farklı dönemlere ait istatistiklerle, Tunus'taki istikrarın saikleri değerlendirilecektir. Çalışma kapsamında ulaşılacak tespitlerin, diğer ülkeler açısından bir rol model olabilme potansiyelini değerlendirme imkânı sunacağı umulmaktadır.

Çalışmanın ilk kısmı, tarihsel arka plan çerçevesinde şekillenecek, bu kapsamda genel itibariyle Tunus tarihi, Fransız işgali ve 1956 y1lında kazanılan bağımsızlıkla yönetime geçen Habib Burgiba ve 1980'li yıllarda darbeyle onun yerini alan selefi Bin Ali dönemleri ele al1nacaktır. Çalışmanın ikinci kısmında Yasemin Devrimi ve ardında yaşanan süreç üzerinde du-

\footnotetext{
3"Tarihsel sosyoloji, geçmiş ile bugün arasındaki ilişkiye evrensel gelişim şemaları giydirmeye çalışma meselesi değildir. Yalnızca bugüne bir tarihsel arka plan tanıtma meselesi de değildir. Bir yandan kişisel faaliyetler, diğer yandansa toplumsal örgütlenme arasında, zaman içinde bilinçli bir biçimde inşa edilmiş olan ilişkiyi anlamaya dönük bir çabadır. Tarihsel sosyoloji, sürekliliğe sahip olan bu inşa
}

rulacaktır. Karşılaştırmalı bir yöntemle "Yasemin Devrimi”" sonrası, Tunus'ta oluşan yönetsel istikrarın nasıl başarıldığ 1 değerlendirilecektir.

\subsection{Tarihte Tunus}

Farklı etnik, dini ve kültürlere ev sahipliği yapmış olan Tunus, Berberiler, Kartacalılar, Fenikeliler, Romalılar, Araplar, Osmanlılar ve Fransızlar olmak üzere birçok medeniyetin etkisinde kalmış iki bin beş yüz yıllık köklü bir tarihe sahiptir.

Tunus'a İslam dini ve Arap kültürünün sirayet etmesi 702 y1lında Emeviler Dönemine rastlamaktadır. 1534 y1lında Osmanlı imparatorluğunun Tunus'u fethetmesi Barbaros Hayrettin Paşa'nın Kuzey Afrika'ya yaptığı sefer neticesinde olmuştur. Sonrasında 1705 'te ülke yönetiminde etkili olan Hüseyin Hanedanlığ Osmanlı İmparatorluğu'ndan otonomlaşmıştır (Perkins2014:17).

$\mathrm{Bu}$ tarihten sonra Tunus, Batı etkisine girmiş, 1881 'de ise Fransa tarafından fiilen işgal edilmiştir. $\mathrm{Bu}$ işgalle birlikte yeni bir yönetim şekli olan Fransız Protektora oluşturulmuş(Perkins2014: 28) ve Tunus için yeni bir dönem, yani sömürge dönemi başlamıştır.

Yeraltı zenginliklerini kontrol eden Fransa, elde ettiği kaynaklarda yararlanabileceği alt yapıyı kurmak kapsamında kara yolları

sürecini toplumsal çözümlemenin odak noktası haline getirir."(PHILIP ABRAHAMS - HISTORICAL SOCIOLOGY). Tarihsel Sosyoloji için detaylı bilgi için: "Ramazan Yelken, Tarih Sosyolojisi, Vadi Yay. 2006, Konya” ve "Elisabeth Özdalga, Tarihsel Sosyoloji, Doğubatı Yay. 2009, Ankara”. 
ve tren yolları inşa etmiştir. Maden ocakları ve alt kademe temizlik işleri gibi kol gücüne dayanan işler Tunuslulara tahsis edilirken, hizmet sektöründe Fransızlar çalıştırılmış, verimli toprakların işlenmesi de Fransız yerleşimcilere bırakılmıştır.

Fransız yönetime karşı ilk tepki eğitim alma firsatı bulan gençler arasında şekillenmiştir. Aldıkları eğitimle eş değer görev talebiyle başlayan tepkiler gittikçe yönetim için rahatsız edici boyutlara varmıştır. Bu gençler özellikle 1898-1901 yıllarında yüksek sesle taleplerini dillendirmelerinden dolayı Protektora yönetimi açısından bir tehdit oluşturmaya başlamıştır. Fransa, Tunusluların modern eğitim almasına mesafeli bir tutum takınmıştır. Victor de Carnières tarafından yayınlanan La Tunisia Française isimli gazetede modern eğitim alan Tunusluların iş konusunda beklentilerinin arttığı ve belli işlere girişte Fransız yerleşimcilerle rekabet ettiğine dair konular işlenmiştir. Dahası Fransız kültürünün Tunus kültüründen üstün olduğu vurgusunu yapan gazete, Tunuslulara verilen eğitimin Fransız yerleşimcilerin sahip oldukları ayrıcalıkları tehlikeye attığını savunmaktadır. Bu yaklaşımı dikkate alan Halk Eğitim Müdürlüğü, 1898 ve 1901 yılları arasında ağırlıklı olarak Tunuslulara eğitim veren on tane Fransız-Arap okulunu kapatmıştır. Buna ek olarak, Eğitim Müdürlüğü 1898'de yeni bir okul kurarak yerleşimcilerin taleplerini karşılamaya çalışmıştır. Öğrencilerin büyük bölümünün Avrupalılardan oluştuğu bu okulda, Tunusluların daha nitelikli işlerde çalışmasını sağlayacak bir eğitim alması engellenmiş ve niteliksiz işlerde çalışmaya yönelik bir eğitim dayatılmıştır.
Fransız yönetimin Müslümanların eğitim imkânlarına erişimini engellemeye dönük politikası, reform yanlısı Tunusluları büyük hayal kırıklığına uğratmıştır (Dursun 2016:215 ve Perkins 2014: 55-60).

Fransa Protektora, aykırı düşünen bu gençlere baskı uygulamış ancak bu baskılar genç Tunusluları örgütlü bir yapılanmaya yönlendirmiştir. Milliyetçi İslamcı bir bakış açısına sahip Düstur (Anayasa) hareketinin kurulması bu tepkilerin sonucudur. Düstur, Arap kimliğini öne çıkaran geçmişteki gibi, İslami kaidelere dönülmesi gerektiğini savunan kişilerden oluşmuştu.

\subsection{Kurtarıcı Bir Lider Olarak}

\section{"Habib Burgiba"}

Tunus'un kıyı şeridindeki Manastır kasabasında doğan Habib Burgiba (1903 - 2000) 1930'larda Tunus'ta Fransızların etkisindeki Sadiki Koleji'ni bitirmiş, ardından Paris'te hukuk ve siyaset eğitimi almıştır. Habib Burgiba'nın Düstur Hareketine katılmasıyla hareket form değiştirmiştir. Burgiba, bu hareketin milliyetçi ve İslamcı yanlarını zamanla eleştirmiş ve köhnemiş bir zihniyet olarak nitelemiştir. Çağdaş medeniyetler seviyesine ulaşma hedefiyle demokratik laik bir düzenin savunusunu yapmıştır. "Toplumların modern ekonomik gelişme aşamasına ulaşmaları için kültürel ve toplumsal bir değişim sürecine ihtiyaç duydukları inancı"(Altun 2011: 13) Burgiba'y1 etkileyen bir modernleşme düşüncesidir. Bu doğrultuda, Düstur Hareketini, Yeni Düstur Hareketi olarak modernleşme düşüncesine atıfta bulunarak yeniden yapılandırmıştır. 
Burgiba, bir yandan Tunus halkıyla İslam merkezli ilişkiler geliştirirken, diğer yandan batı kültürünü kutsayan, laiklik savunusunu önemseyen bir tutum takınmış, bu çerçevede bağımsızlık mücadelesine girişmiştir. Burgiba'nın liderliğindeki Yeni Düstur Hareketi uzun soluklu bir mücadele sonunda, kan dökülmeden bağımsızlık kapısını açmıştır.

Fransız hükümeti, Tunusluların Protektora yönetiminin sonlanması talebini olumlu karşılamış ve 20 Mart 1956'da Tunus'un bağımsızlığını resmen tanımıştır'. 1957'de ise Kurucu Meclis cumhuriyetin kuruluşunu ilan etmiş ve Burgiba'yı cumhurbaşkanı olarak belirlemiştir (Dursun 2016:236). Bağımsızlık sonrasında Tunus'un en güçlü kişisi olarak yönetime gelen Burgiba, Tunus'ta çağdaş medeniyet seviyesine ulaşma fikrini hayata geçirme çabasına girişmiştir.

Sosyal değişmenin ana dinamiğini oluşturan faktör değiştirme gücünün bizde olduğuna olan inancımızdır. Etrafımızdaki şartları olduğu gibi kabul etme eğilimi, toplumu daima daha iyiye götürme isteği kendi başına hiç kuşkusuz yadırganamaz: Toplumun insan iradesiyle değiştirilebileceği inancı gücümüzün belki en yaygin siyasal ilkelerinden birisini(Mardin, 1999) oluşturmaktadır. Burgiba da bu gücü kendinde görmektedir. Bu doğrultuda öncelikle köhnemiş, tarihe karışmış ve gelişmenin değişmenin önünü tıkayan dinsel ve geleneksel olanın toplumdan temizlenmesi gerekliliği üzerine toplumu inşa etmiştir. Toplumdaki bu dönüşümü gerçekleştirmek için tek parti iktidarı ile yönetimde rakipsiz kalması gerektiğine inanmıştır.

Modernleşmenin toplumsal alanda varlığını hissettirmesiyle önce Batı'da ve sonra Batı dışı toplumlarda dinin yeri ve rolünde değişim yaşandığı ortadadır(Albayrak 2016: 26). Batı merkezli laik demokratik toplum fikri Burgiba'da hâkim düşünce olsa da, toplumun İslam ile münasebetinin tarihi boyutunu dikkate alarak İslam'dan tamamen bir kopuşa yönelmemiştir. Kuran-1 Kerim'den "Rahman olan Allah'ın adıyla" ifadesinin yeni anayasanın başında yer alması, İslami ilkelere atıf yapan Burgiba'nın kendi rejiminin meşruiyetini sağlamak için seçtiği stratejiyi yansıtmaktadır. Esasen, dini devlet sisteminin bütünüyle içine alarak, yeni rejim hem topluma İslam konusundaki kendi yorumunu dayatma gücünü edinmiş hem de İslamcı - Milliyetçi taraftarları gibi İslami gerekçelerle muhalif bir hareketin oluşmasına engel olmak istemiştir. Toplumsal tepkileri minimize etmek için Anayasa'ya Tunus'un dini İslam'dır maddesini koymuştur.

Burgiba'nın etkisiyle 1 Haziran 1959'da yürürlüğe giren Anayasa büyük ölçüde Batı ülkelerinde kabul edilen anayasalara benzemekle birlikte, din ve devlet arasinda net bir ayrım yapmamasıyla dikkat çekmektedir (Dursun 2016:239). Ancak bununla birlikte katı bir laiklik uygulamasının yapıldığını göreceğiz.

Dini mahkemelerin kaldırılması, Medeni Kanun'un kabul edilmesi, (13Ağustos 1956) eğitim sisteminin merkezileştirilmesi ve

\footnotetext{
${ }^{4}$ http://www.mfa.gov.tr/tunus-siyasi-gorunumu.tr.mfa, Erișim tarihi: 09.01.2018
} 
Kur'an kursları ile devlet okulların birleştirilmesi Burgiba'nın attığı laik adımlar arasında dikkat çekenlerdendir. Bunlarla birlikte, Burgiba modern bir ulus devlette geleneksel eğitim sisteminin sürdürülmesinin uygun olmadığını savunmaktaydı. Tunus eğitim tarihinde kayda değer bir öneme sahip olan geleneksel ve ağırlıkla dini eğitimin verildiği Zeytune Üniversitesi ${ }^{5}$ Milli Eğitim Bakanlığına bağlanmış. Zeytune Medresesi'nin müfredatı tamamen değiştirilmiş yeni bir müfredat oluşturulduktan iki y1l sonra da Tunus Üniversitesi'nin bünyesinde bir ilahiyat fakültesi olarak devletin kontrolü altına alınmıştır(Perkins 2014: 146). Dini ritüellere yönelik laik uygulaması ise kamu kurumlarında ve okullarda başörtü yasağının getirilmesi olmuştur. Burgiba'nın, modern bir toplum olan batıda başörtüsü yok ve insanların bir bez parçasına bürünmelerine gerek yoktur şeklindeki açıklamaları üniversite de dâhil olmak üzere bu yasağı yaygınlaştırmıştır. Ayrıca 5 Şubat 1960'da Ramazan ayının başlamasından üç hafta önce, Burgiba geri kalmışlıkla mücadele etmenin önemine değinmiş ve yoğun bir ça-

${ }^{5}$ Zeytune Medresesi/Üniversitesi: Hicri 79 (698 miladi) yılında kurulan Zeytune bir cami olduğu kadar, İslami ilimlerin yüksek seviyede tahsil edildiği bir yüksek eğitim müessesesi... Zeytune Camii tarih boyunca yalnızca, İslam mimarisinin eşsiz ve estetik bir örneğini temsil etmekle kalmamış aynı zamanda kurulduğundan itibaren bir ilim merkezi rolü icra etmiş olması hasebiyle bir nevi ilk İslam üniversitesi olma özelliğine de sahip olmuştur. Müştemilatındaki ders halkalarından ve civarındaki medreselerden İmam Sahnun gibi birçok âlim ve fikıhçının yanı sıra din, siyaset, fikir ve edebiyat adamı çıkarmıştır.

İmam Malik'in meşhur öğrencilerinden Ebû Hasan Ali b. Ziyad et-Tunûsî, Maliki fakihi ve Kayravan kadısı Esed b. Furat, Malikî fıkhının temel kitapla- lışma stratejisi belirlemiştir. Ekonomik istatistiklerin Ramazan Ay’ında düşüşe geçtiğini gören Burgiba, işçi performansındaki düşüşün önüne geçmek için Ramazan orucunun terk edilmesi gerektiğini dile getirmiştir. Böylelikle, Burgiba dini geleneğin ve Müslüman kültürünün en önemli ibadetlerinden birini açıcça eleştirmiş ve bu konuda yasak getirme yetkisini de kendinde görmüştür. Geri kalmışlığa karşı cihat edilmesi gerektiğini savunan Burgiba'ya göre, cihat/çalışmak oruçtan çok daha önemli bir ibadettir ve cihat durumunda bazı farzların terk edilmesinde herhangi bir sakınca yoktur(Dursun2016:248). Burgiba'nın "Ramazan boyunca çalışma duruyor. Bizler Üretimi arttırmak için imkânsızı zorlarken neredeyse bir hiç uğruna nasıl bunun y1kılmasına müsaade edebiliriz? Bunu yapamayız. Dinin böyle bir isteği olduğunu tartışmalı buluyorum... Bu, dinin aşırı bir yorumudur... Din, yaşamının zorluklarını arttırmak için değil, azaltmak için vardır" (Burgiba 1976: 128 ve Aktaran: Dursun2016:248), şek-

rından olan "el-Müdevveninin hazırlanmasında büyük emeği olan ve keskin ilmi buluşları olması sebebiyle kendisine "Sahnûn" lakabı verilen Sahnûn B. Abdüsselam B. Saîd bu ekolün öncü ve sembol isimlerindendir.

"Sosyoloji ilminin kurucusu" kabul edilen sosyal tarihçi Abdurrahman İbn Haldun, ünlü fakih İbn Arafe, meşhur mutasavvif Ebu'l-Hasan eş-Şazeli, elEzher şeyhlerinden Muhammed Hıdr Hüseyin, ünlü makâsıdeı Tahir b. Aşur ve daha birçok ilim adamı Zeytune 'de yetişmiş. (http://sahniseman.org/zeytunede-egitim-yili-basliyor/ ve http://www.ekrembugraekinci.com/makale.asp?id=295, Erişim tarihi: 27.01.2018 
lindeki argümanlarla gerekçelendirdiği yaklaşımı, doğal olarak başta mollalar olmak üzere, Müslüman halk içinde tepki yaratabilmiştir.

Toplumsal değişimin İslam dini aleyhine gittikçe sertleşmesi, Raşid Gannuşi ve arkadaşlarının camilerde ve ev sohbetlerinde oluşturdukları illegal sohbet halkalarını, İslami Yöneliş Hareketi adıyla örgütlü bir forma dönüştürmelerine zemin sağlamıştır. $\mathrm{Bu}$ yeni hareket uzun süredir iktidarda olan Habib Burgiba karşısında alternatif bir siyasal söylem oluşturmaktan ziyade dini ritüellere yönelik yasakların kaldırılması üzerinde yoğunlaşan bir söylem geliştirmiştir. Hareketin siyasal erke yönelik y1kıcı faaliyeti olmamasına rağmen Habib Burgiba'nın sert müdahalesine maruz kalmıştır. Her ne kadar, İslami kimlik merkezi bir öneme sahip olsa da, hareket toplumun sorunlarını bir bütün olarak değerlendirmiş ve dini alan dışındaki sorunları da dikkate almıştır. Burgiba yönetimi, harekete karşı tutumunu başından itibaren net biçimde ortaya koymuş, Gannuşi, İslami Yöneliş Hareketi hakkında basın önünde açıklama yaptıktan sadece beş hafta sonra hareketin diğer liderleri ile birlikte hapse atılmıştır. 18 Temmuz 1981'de, aralarında Gannuşi'nin de bulunduğu İslami harekete mensup 107 kişiyi tutuklamıştır. Örgüt üyelerinin bir kısmı elli yıl hapis cezası alırken, Gannuşi on yıl hapse mahkûm edilmiş ve yalan haberler yaymakla suçlanmıştır(Gannuşi 1981: 274-275).

Habib Burgiba, tek kişi iktidarı ile Tunus'u çağdaş medeniyetler seviyesine varmak şeklinde formüle ettiği hedefi doğrultusunda baskı unsurlarını sonuna kadar kullanarak otoriter bir rejim kurmuştur. Gerek siyasi partilerin kurulmasına izin verilmemesi, gerekse devletten bağımsız sivil toplum örgütlerinin engellenmesine yönelik bürokratik kısıtlamalarla, otoriter yönetime karşı alternatif yapıların ortaya çıkmasına bariyer konulmuştur.

Ülkedeki ekonomik tablo da parlak değildi. Bir yandan üniversiteli işsizler ve alım gücü asgari geçimin çok altında olan Tunusluların yaşadığı sefalet, diğer yandan ülkedeki zenginliği elde tutan bir azınlık tablosu toplumdaki kargaşa için uygun zemin sunuyordu.

\subsection{Darbeyle Gelen Umut: "Zeynel}

\section{Abidin Bin Ali”}

Tunus'ta Hammam Sousse'de doğan ve hala Suudi Arabistan'da yaşamını sürdüren Zeynel Abidin Bin Ali(1936 - ...) başbakanlık görevini yürütürken, kaos ortamını ve Burgiba'nın sağlık sorunlarını gerekçe göstererek 7 Kasım 1987'de otuz bir y1ldır yönetimde olan Burgiba'yı koltuğundan indirerek (bir nevi darbeyle) kendisini Cumhurbaşkanı ilan etmiştir.

Bin Ali, yönetime geldiği ilk dönemde İslam, siyasi partiler ve sivil toplum kuruluşları üzerindeki kimi yasakları ve kısıtlamaları kaldırmıştır. Zeytune Medresesi'ne özerkliğin geri verilmesi, devlet radyo ve televizyonunda ezan okunmasına izin verilmesi ve Zeytune ile işbirliği yapılarak imamların yetiştirilmesi, ülkenin dini meselelerini görüşmek üzere Yüksek İslam Konseyi kurmak şeklinde adımlar atmıştır. 1988 yılında gerçekleştirdiği umre ziyareti ise kamuoyunda büyük yankı uyandıran ve ihramlı fotoğraflarılyla gazetelerde geniş yer bulan (Shahin1998:100) sembolik manası büyük bir adımdı. Bin Ali, siyasal sistemi serbestleştirici 
bir tutumla sahneye çıkmış, siyasi parti kurmanın önündeki engelleri kaldırmış çok partili dönemi başlatmıştır. İslami Yöneliş Hareketi, bu dönemde, siyasal bir forma bürünmüş ancak dini bir isimle parti kurma yasağından dolayı En Nahda Partisi olarak Gannuşi liderliğinde siyasi faaliyetlerine başlamıştır. Bin Ali Tunuslular için bir nimet olarak algılanmış kısmi bir özgürlük ortamı oluşturmuştur. Ancak bu durum 1989 seçimlerine kadar sürebilmiştir. Bu seçimlerde her ne kadar birinci parti çıksa da kendisine en yakın olan Nahda'nın oyların \%20'sini alması Bin Ali'yi hiç memnun etmemiştir. Elde ettiği halk desteğiyle güçlü bir rakip haline gelmiş En Nahda kapatılmış, lideri Gannuşi ve binlerce parti üyesi tutuklanmış veya sürgün edilmişlerdir. Askeri Mahkemede Temmuz 1992' de yargılanan 279 aktivistin yargılanmas1nın ertelenmesini talep eden Tunus İnsan Hakları Ligi (LTDH; Ligue Tunisien nedes Droits de l'Homme), sanıkları konuşturmak için işkence kullanılıp kullanılmadığının incelenmesi gerektiğini vurgulamıştır. Bununla birlikte, yargılama sonunda En-Nahda'nın önde gelen isimleri çok ağır hapis cezalarına çarptırılmış$\operatorname{tir}($ Dursun 2016:278).

Bin Ali, Burgiba gibi sosyal değişimin dinamiklerinin merhaleci bir yaklaşımla toplumu eğitmekten geçeceğine inanmış ve de bu eğitimi tepeden inme baskıcı anti demokratik yöntemlerle uygulamayı seçmiştir. Kendisi bu durumu şu sözlerle ifade etmiştir: "Asıl önemli olan halkın demokrasiden ne anladığıdır (...) demokrasinin gelişmesi bir eğitim ve aşama aşama ilerleme meselesidir. Bunun böyle ol- ması, özgürlük ve adalet olmadığı anlamına gelmez. Bunu aşamalı bir şekilde yapmak, öncelikle okul seviyesinde bu fikri öğretmek ve yanlış adımlar atmaktan kaçınmak anlamına gelir. Halkın eğitilmesi gerekir. Demokrasi, başlı başına bir kavramdır. Demokrasi sadece siyaset değil, aynı zamanda sağlık hizmetleri, barınma ve çalışma hakkıdır. Kalkınma olmadan demokrasi olamaz, demokrasi olmadan ise kalkınma olamaz. Fakat tek başına ifade özgürlüğünün olması halkın iş ve içecek su bulmasını sağlamıyor. Eğer halk zihinsel olarak demokrasiye hazır değilse, bu bir felakete yol açabilir"(Bin Ali1994:111 Aktaran:Dursun2016:287). Bin Ali’nin öngördüğü demokrasi çerçevesinin s1nırları 2004 Cumhurbaşkanlığı seçiminde bir kez daha somutlaşmıştır. Tek aday olarak seçimlerde \%98 oyla seçilmiştir.

Bin Ali dönemi Burgiba sonrası Tunus için ekonomik ve toplumsal bir refah sunmamış işsizlik her geçen gün artmış ülkenin zenginlikleri kıyı kesiminde yaşayan, hammadde ihraç eden bir azınlık tarafından idare edilmiştir. Batı yanlısı politikalar doğrultusunda hareket etmiş. Kitle iletişim araçlarından TV, Radyo ve Gazete gibi yayın ve basım organlarından aykırı seslere yasak getirilmiş ve halkın haber alma hürriyeti kısıtlanmıştır. Yine bu dönemde Farklı siyasal yapılara ve demokratik hak taleplerine sert karş1lık verilmiştir.

\section{Yasemin Devrimi}

Toplumsal hoşnutsuzluğun üst seviyelere çıtığg Bin Ali döneminde ara ara sosyal krizlerin baş göstermiştir. Ancak bu tür protestolar ve ayaklanmalar polisin orantısız ve sert şiddeti ile bastırılmıştır. Bastırmak sorunları 
çözmekten ziyade, erteleyen bir sonuç yaratmış, süreç içerisinde toplumdaki sıkışmayı besleyen bir sarmala dönüşmüştür.

Üniversite mezunu olan 26 yaşındaki Muhammed Buazizi'nin, 17 Aralık 2010 tarihinde, şehir merkezinde tezgâhta meyve sebze satarken, yasak yerde satış yaptığ gerekçesiyle zabitalar tarafindan para cezası kesilmesi ve akabinde tezgâhına el konulması, hakarete maruz kalmıştır. Belediyeye giderek para cezasını ödeyip fakat tezgâhını geri alamaması(Tanrıverdi 2011: 53) Tunus'ta yeni dönemi başlatacak olayların fitilini ateşlemiştir. Dokuz kişilik bir ailenin tek geçim kaynağı olan Buazizi, evine gelip aldığı yanıcı yakıcı madde ile belediye binasının önünde kendisini yakmasıyla Arap Baharı süreci başlamıştır. Daha ilk günden bu duruma tepkiler sosyal medya üzerinden(facebook, twitter vb. gibi) çığ gibi büyümüş, halk sokağa inmiştir. Geniş çaplı protestolar her geçen gün büyük katılımlarla tüm Tunus'a yayılmıştır. Bu protestolara Bin Ali yönetimi çok sert müdahalede bulunmuş birçok kişi ağır bir şekilde yaralanmıştır. Gerek ABD gerekse Avrupa'yla olan iyi ilişkilerine güvenerek protestoları bastırmak için müdahalenin şiddetini artırmıştır. Ancak sessiz kalınması beklenen batı bu duruma karşı sessiz kalmamış Bin Ali yönetimini eleştirmiş, şiddetin dozunu azaltmasını istemiştir. Halk eylemleri karşısında daha fazla dayanamayan Bin Ali çareyi 14 Ocak 2011 y1lında ülkeyi terk etmekte bulmuştur(Tanrıverdi 2011: 53-54).

Tunus, Sosyal değişmenin üstten dayatmacı ve bir kişinin iradesiyle gerçekleşebileceği inancının akıbeti için çarpıcı bir örnektir. Habib
Burgiba ile başlayan Bin Ali ile devam eden otoriter yönetimin, modernleşme eksenli politikalar1, toplumu adeta bir toplumsal mühendislik nesnesine indirgediği ölçüde, karşıtını da doğurmuş ve bir nevi kendi akıbetini belirleyecek gelişmelerin zeminini kendisi yaratmıştır. Otoriter yönetim devrilmesine yol açan ayaklanmayı tetikleyen birçok unsurdan öne çıkanlar şöyle sıralanabilir:

a) Siyasal partilere konulan engeller,

b) Farkl kesimlerin istemlerini sahiplenecek sivil toplum örgütlerine hayat hakkn taninmamasl,

c) Güvenilir bir yöneticinin olmayışıl.

\subsection{Devrim Sonrası Siyasi Partiler}

Devrim sonrası Tunus'ta beklenen yönetimsel boşluk ve kargaşa ortamı oluşmamıştır. Ama tarihteki birçok tecrübe göstermiştir ki, halk ayaklanmaları sonucu yönetimlerin devrilmesi ve/veya demokrasiye geçiş çabaları, kamu otoritesinin zayıflaması ya da kimi zaman çökmesi sonucu kısa vadede daha kaotik bir ortama yol açmaktadır(Özdemir 2017: 41). Devrimle birlikte mevcut siyasi partilerin kapatılmamas ve önceki süreçte disfonksiyonel olan Nahda partisinin aktif şekilde sahneye çıkması bu durumun aşılmasında önemli bir rol oynamıştır.

Böylece siyasi partilerin demokrasi için vazgeçilmez unsurlar olduğu bir kez daha ortaya çıkmıştır. Demokrasi siyasi partiler, serbest seçimler ve sivil toplum kuruluşlarının varlığıyla doğrudan ilişkilidir. Tek partili siyasi sistemler seçim kurumlarına sahip olsa bile demokratik sistemler değildir. Demokratik sistemlerde farklı siyasi düşüncedeki insanları temsil eden birden çok partinin bulunması, bunların 
herkesin arzu ettiği ve uygun bulduğu hürriyet ve eşitlik içerisinde seçme ve seçilme imkânına sahip olması gerekir(Arslantürk ve Amman 2014: 337-338).

Samuel P. Huntington (1996), ülkelerin demokrasiye geçişlerini ve demokrasiden uzaklaşmasını uluslararası ilişkilerle ilintili olarak görmekte ve bunu ispatlayan bazı veriler ortaya koymaktadır. Huntington, otoriter yönetim anlayışının olduğu tek partili sistemi, daha sonraki dönemlerde de askeri veya kişisel diktatörlüğe dayalı rejimlerden çok partili demokratik düzene geçiş olduğunu belirtmektedir.

Tunus'ta devrim sonrasinda, demokratikleşme yönelimi çerçevesinde siyasi parti açma önündeki bürokratik engeller kaldırılmış ve Tunuslular eşitlik içerisinde seçme ve seçilme imkânına kavuşmuştur. Böylelikle devrim öncesinde yedi partinin faaliyet gösterdiği Tunus'ta, devrim sonrası dönemde siyasi parti kurmanın kolaylaşmasıyla birlikte parti sayısı yüzü aşmıştır. ${ }^{6}$ Kendisini merkez sağ, merkez sol, merkez, sosyalist, sağcı, çevreci, solcu, İslamcı, bağımsızlıkçı, Marksist, Marksist Leninist, yeni solcu, Arap Birliği yanlısı, işçi yanlısı, İlerici, reformist, sosyal demokrat, sosyal özgürlükçü, komünist, bilimsel sosyalist vb. şekilde niteleyen partilerin seçimlere katıldı̆̆ gözlenmiştir. ${ }^{7} 23$ Ekim 2011 'de yapılan ilk seçimin sonuçları şöyleydi: 217 sandalyeli meclisin \%37 oyla 89 sandalye muhafazakâr Nahda

${ }^{6}$ http://file.setav.org/Files/Pdf/devrimden-demokrasiye-tunusun-secimi.pdf, Erişim Tarihi: 02 Ocak 2018.
Partisi almış, solcu Cumhuriyet İçin Halk Kongresi 29 sandalye, Et-Tekettul Partisi ise 21 sandalye alarak Nahda ile adına "Troyka" denilen üçlü bir koalisyon hükümeti kurmuşlardır(Okumuş 2015:39). Birkaç geçiş hükümeti denemesinin akabinde 2014 Ekim ayında yeni anayasa çıkarılması ve nihayetinde Aralık 2014'te Cumhurbaşkanlığı seçimi yapılmıştır. Bu seçimde dikkate değer olay Nahda'nın aday göstermemesidir. Bunun da etkisiyle laik seküler ama dine karşı hoşgörülü olacağını seçim beyanlarında dile getiren El-Baci Kaid es-Sibsi (88) oyların \%55'ini alarak seçimle gelen ilk Cumhurbaşkanı olmuştur(Okumuş 2015: 49). Bu süreci El-Cezire TV'nin yazarlarından Larbi Sadiki tarafından şöyle ifade edilmiştir: "Belki de gerçek bir demokraside bu oyların dağılımı, devlet ve toplumun karşılıklılığ temelinde siyaseti yeniden başlatmak için olanak ortaya çıkarmiştır. ${ }^{8}$

23 Ekim 2011'de yapılan ilk seçimde, 217 sandalyeli meclisin 89 sandalyesini İslamcı Nahda Partisi, 29 sandalyesini solcu Cumhuriyet İçin Halk Kongresi, 21 sandalyesini Et-Tekettul Partisi almıştır. Bu üç parti "Troyka” denilen üçlü bir koalisyon hükümeti kurmuşlardır(Okumuş 2015:39). Birkaç geçiş hükümeti denemesinin akabinde 2014 Ekim ayında yeni anayasa kabul edilmiş ve akabinde Aralık 2014'te Cumhurbaşkanlığı seçimi yapılmıştır. Bu seçimde dikkate değer olay Nahda'nın aday

${ }^{7}$ http://file.setav.org/Files/Pdf/devrimden-demokrasiye-tunusun-secimi.pdf, Erişim Tarihi: 02 Ocak 2018.

${ }^{8}$ http://www.aljazeera.com/indepth/opinion/2011/05/201152481943157780.html, Erişim Tarihi: 02 Ocak 2018. 
göstermemesi olmuştur. Böylelikle laik seküler ama dine karşı hoşgörülü olacağını seçim beyanlarında dile getiren El-Baci Kaid es-Sibsi oyların \%55'ini alarak seçimle gelen ilk Cumhurbaşkanı olmuştur(Okumuş 2015: 49). Bu süreç El-Cezire TV'nin yazarlarından Larbi Sadiki tarafından şöyle ifade edilmiştir: "Belki de gerçek bir demokraside bu oyların dağılımı, devlet ve toplumun karş1lıklılığ temelinde siyaseti yeniden başlatmak için olanak ortaya çıkarmıştır. ${ }^{9}$

Gannuşi, demokrasi açısından seçim sonuçlarını gayet olumlu karşılamış, çok partili hayatın bir kazanım olduğunu ifade etmiştir. Gannuşi’ye göre, "Devrim öncesinin az katılımı ve \%98 oyla seçilen Cumhurbaşkanlığına nazaran $\% 60$ katılımlı ve Cumhurbaşkanın $\% 55$ oy almasıyla işleyen bir demokrasi açısından güzel bir noktaydı"(Gannuşi 2016: 94-95).

\subsection{Tunus'ta Devrimden Önce ve Sonra Sivil Toplum Örgütleri}

Devlet iktidarının sınırları ve meşruluğuna ilişkin tartışmada sosyal kuvvetler olarak ön plana çıkan sivil toplumdur. Demokrasinin temelini, yurttaşların devlete ve siyasal kurumlara duyduğu güven oluşturur. Sivil toplum örgütleri toplumsal ve siyasal düzeyde güven üreten ve yayan kurumlar olarak, devletin meşruluğunu güçlendirir(Erdoğan Tosun 2001: 174). Vatandaşlar yöneticilerini/vekillerini üye oldukları gruplardan(STK)seçtiklerinde hükümetin meşruluğuna olan güvenleri artacaktır. A.
Lincoln'ün ünlü deyişiyle, "halkın halk tarafından, halk için yönetimi” olarak tanımlanan devlet yönetimi(Sartori, 1993, s. 36) yaklaşımı fiili hayatta görünür olacaktır. Sivil toplumun yüklendiği işlevler demokrasi için elzemdir. Larry Diamond'a göre sivil toplumun işlevleri şöyle tanımlanmıştır: Devlet iktidarını kontrol, katılım düzeyini yükseltme, demokratik tutumlarının geliştirilmesi, çıkarların şekillendirilmesi ve eklemlenmesi, kutuplaşmaların yumuşatılması, yeni siyasal liderlerin yetiştirilmesi, siyasal partilerin demokratikleştirilmesi, bilgiyi toplumun geniş kesimlerine yayma, yeni fikirlerin yayılmasını sağlama ve siyasal sistemin halka karşı sorumluluğunu artırmaktır(Diamond1994: 168, Erdoğan Tosun 2001: 179-180).

Tunus'ta Sivil Toplum Örgütleri gerek legal gerekse illegal düzeyde organize olmaya Fransa Pretetokrası sonrası dönemde bağımsılık mücadelesi sürecinde başlamıştır. $\mathrm{Bu}$ dönemde işgal karşıtı söylem baskılardan dolayı illegal bir faaliyet bağlamında şekillenmiştir. Fransız işgali sona erdikten yani 1956 sonrasında, Habib Burgiba yönetiminde STK'ların legal bir hal alıp kurumsallaştığı görülmektedir. Ne var ki, demokratik bir siyasal yapıya ulaşı1madığından bu kuruluşlar özerk ve bağımsız bir forma bürünememişlerdir. Bunu STK yöneticilerinin Burgiba tarafindan atanmasından anlamaktayız. Aynı zamanda rejim karşıtı söylem çerçevesinde şekillenen STK'ların kuruluşuna da firsat verilmemiştir.

\footnotetext{
${ }^{9} \mathrm{http}: / / \mathrm{www}$. aljazeera.com/indepth/opinion/2011.05.201152481943157780.html, Erişim Tarihi: 02 Ocak 2018.
} 
Burgiba döneminde, demokrasisinin gereği olarak görüntüde sivil toplumun kurumsallaşması sağlanırken, aynı zamanda bu kuruluşların tek parti rejimine karşııt bir ses oluşturmayacak bir nitelik arz etmesi için de sıkı önlemler alınmıştır. "Bu bağlamda Burgiba'nın izlediği en temel yöntem, kimi kuruluşların yönetici kesimine partinin üst düzeylerinde yer vererek bu STK'lar ile işbirliği yapmak olmuştur”(Köktaş2016:3).

Böylelikle STK'ların en önemli özelliklerinden biri olan devletten bağımsız kalma ve kar amacı gütmeksizin çalışma prensibi ortadan kalkmış ve devlet güdümlü bir STK anlayışı yerleşmiştir. Böylelikle Burgiba döneminde birçok STK'nın mali desteği devlet tarafından sağlanmış, devletten bağımsız olanlar ise devletin ciddi bir baskısına maruz kalmışlardır. Ayrıca çıkarılan kanunla STK'ların hayır kuruluşu, kadın hakları, spor, sanat, bilimsel, kültürel kuruluşlar olabilecekleri fakat demokrasi, insan hakları gibi politik kuruluşlar olamayacaklarına yönelik sınırlama getirilmiştir. İlgili yasada dikkat çeken bir diğer husus ise STK'ların kurumsal işleyişleri için İçişleri Bakanlığı'ndan onay almaları gerektiğine yönelik düzenlemeydi. Bu kanuna göre İçişleri Bakanlığı herhangi bir STK'ya kanun ve ahlaki değerlere aykırılık, toplum düzenine tehdit oluşturduğu gerekçeleriyle izin vermeme yetkisine sahipti”(Köktaş 2016: 3-4).

Habib Burgiba'dan sonra darbe yolu ile iktidara gelen Bin Ali'nin aşağıda Grafik 1'den de anlaşılacağı üzere sivil toplum kuruluşu açmanın önündeki engelleri kaldırmasıyla, 1986'da 156 olan STK say1s1 1989'da 1738'e ulaşmıştır. Bin Ali, Tunuslular için bir umut olmuştur. Ancak bu durum uzun sürmemiştir. Seçimlerde kendisine rakip olarak Nahda Partisinin fark edilir oy almasını kendisi için tehlike olarak görecek ki demokratik tutumunu değiştirmiştir. Selefi Burgiba gibi muhalif ve tehlikeli gördüğü STK'ların kapanması veya pasifize edilmesi için içişleri bakanlığına yetki vermiş ve detaylı soruşturmalardan geçirilen birçok sivil toplum kuruluşu kapattırmıştır.

"Yasemin Devrimi" sonras1 sivil toplumun durumuna bakıldığında ise, STK'lar üzerinde Bin Ali döneminde getirilen kısıtlamaların neredeyse tamamının kaldırıldığ 1 ve bu kısıtlamaların kaldırılmasıyla birçok yeni sivil toplum kuruluşunun ortaya çıktı̆̆ görülmektedir. 18 Şubat 2011'de geçici hükümet Devrimci Hedefleri Gerçekleştirme, Demokratik Geçiş ve Siyasi Reformlar Yüksek Kurulunu kurmuş ve bu kurul vasitasiyla da STK'lar konusunda koruyucu yasalar çıkarmıştır. Yeni çıkarılan bu koruyucu kanun ile sivil toplum örgütlerinin siyasi konulara da dâhil olması yasallaştırılmıştır. Ayrıca yapılan kanun değişikliği ile artık bir sivil toplum örgütünün kurulması için İçişleri Bakanlı̆̆ı'ndan izin almak yerine yalnızca belediyelere kayıt yaptırılması da yeterli hale getirilmiştir. Böylelikle bürokratik engeller minimize edilmiştir. Birçok yeni STK'nın ortaya çıkışına zemin hazırlayan bu değişiklikler ile 2010 Aralik ayında 8 bin olan STK'ların üye sayısı 2011 Haziran ayı itibariyle 20 bine ulaşmıştır(Köktaş 2016: 3-6). 


\section{Grafik 1: Tunus'ta yeni STK'ların kuruluşlarının yıllara göre dağılımı (1980- 2012)}

3

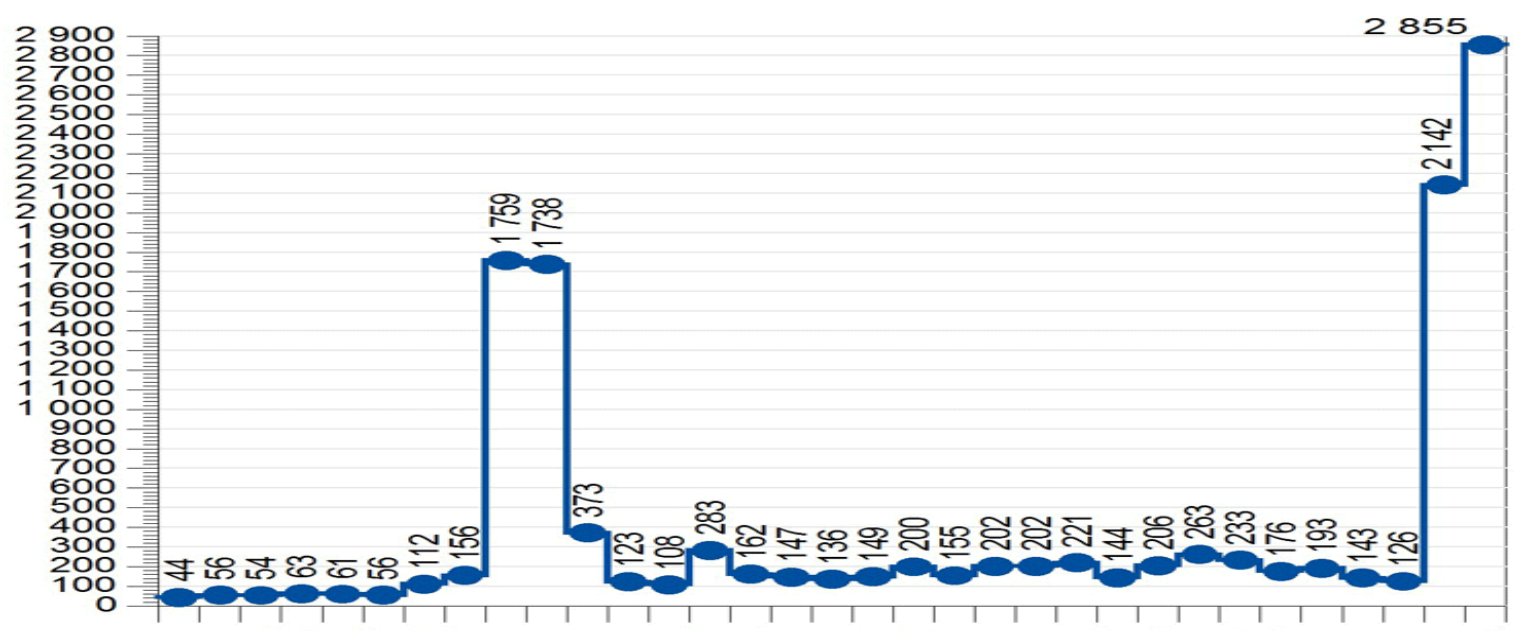

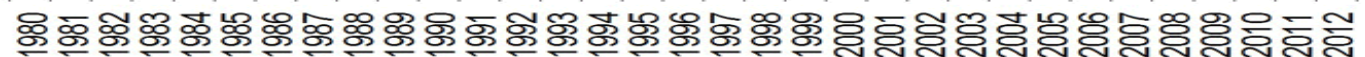

Kaynak: Study on Civil Society Organizations in Tunisia", Foundation For The Future, Ocak 2013, s. 7

(Source: Data Base IFEDA)

2011 öncesinde sivil toplum örgütlerine bakıldığında(Grafik 1) bunların yalnızca ulusal hükümetin politik sisteminin işlemesine katkı sağlayan birer çarktan ibaret olduğu görülür ve bu söz konusu örgütler toplumsal gerçeğin kendisiyle uyuşmayan ve toplumdaki asıl problemlere 1şık tutmaktan uzak kuruluşlardır. Hükümet güdümünde olmayan sivil toplum kuruluşları ise oldukça azınlıkta kalmıştır. Bunlar arasında UGTT (Tunus Genel İşçi Sendikası), Tunus İnsan Hakları Derneği (LTDH), Tunus İşkence Karşıtı Derneği (ALTT), Tunus Özgürlükler Ulusal Konseyi (CNLT) ve feminist organizasyonlar öne çıkmaktadır ${ }^{10}$

Grafik 1 ve 2'den de anlaşılacağı üzere Bin Ali’nin yönetime geldiği 1987 yılından 1989 y1lına kadarki evredeki, kısmi özgürlük ortamında STK’larda gözle görülür bir artış gözlenmiştir.

10"Study on Civil Society Organizations in Tunisia", Foundation For The Future, Ocak 2013, s. 7-8
Yalnızca 1988 yılında 1603 yeni STK açılmıştır. Bir diğer yükseliş ise hem nicelik hem de nitelik açısından "Yasemin Devrimi" sonrasında gözlenmiştir.

Grafik 2 Tunus’taki sivil toplum kuruluşlarının üye sayısının özelikle Bin Ali’nin yönetime geldiği 1987'den başa geldikten sonraki ilk seçimin yapıldığı 1990'a kadar büyük bir artış yaşandığını göstermektedir. Bir diğer yükseliş 14 Aralık 2010 Yasemin Devrimi sonrası süreçte yaşanmıştır. Sivil toplum kuruluşlarına üye olmanın önünde bulunan bürokratik engellerin, siyasi engellerin kalkması, prosedürlerin azaltılması ve izin sürecinin kısmen kalkması etkili olmuştur. Örgütlenme, her kesimden insanın bir araya gelerek oluşturduğu yasal dernekler ile gerçekleştirilmiştir. "18 Şubat 2011'de geçici hükümet Devrimci Hedefleri Gerçekleştirme, Demokratik Geçiş ve Siyasi Reformlar Yüksek 
Kurulunu kurmuş ve bu kurul vasitasıyla da STK'lar konusunda koruyucu yasalar çıkarılmıştır”(Köktaş 2016:5). Çıkarılan bu yasa ile
STK'ların çoğalmasında ve siyasi içerikli konulara yönelmelerinden müdahil olabilmesinde etkili olmuştur.

\section{Grafik 2: Tunus'ta STK'ların üye sayısına göre yıllara göre dağılımı (1980- 2012)}

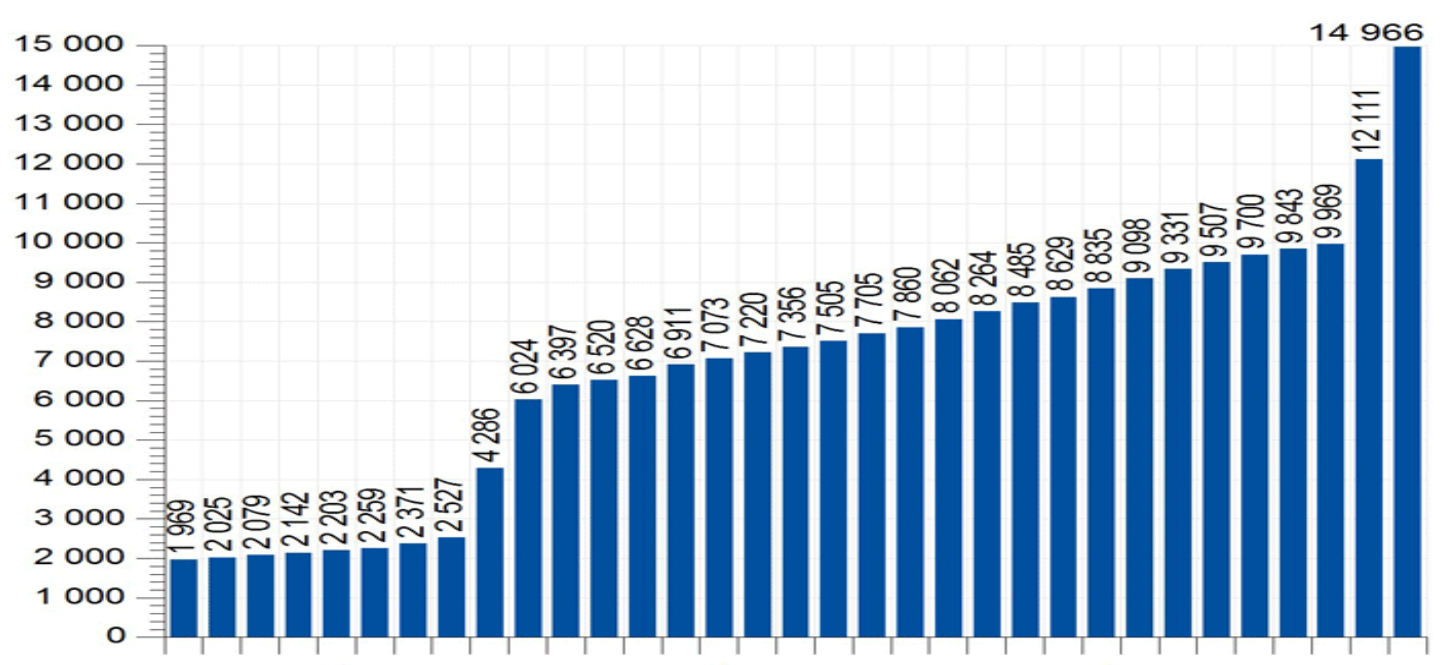

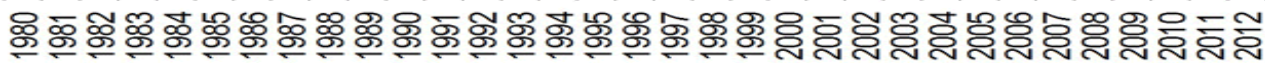

Kaynak: Study on Civil Society Organizations in Tunisia”, Foundation For The Future, Ocak 2013, s. 7

(Source: Data Base IFEDA)

Yukarıdaki grafik 1 ve 2'den de anlaşıldığ üzere "Yasemin Devrimi" sonrası dönemde STK sayılarındaki artış, Burgiba ve Bin Ali dönemlerindeki bask1 unsuru ve yasakların varl1ğını bize göstermektedir. Bu dönemler arasındaki sayısal farkl111klar toplumsal teveccühün hangi yönde olduğunu ve demokrasi açısından devrim sonrası sürecin olumlu sonuçlarını göstermektedir. Öyle ki her çevreden insanın kendisini ifade edebilmek için bir temsilci bulması toplumsal konsensüsü sağlamada önemli bir etken olmuştur. Demokratik sivil toplum özgür ve özerk kamusal tartışmanın alanını farklı gruplara ve beklentilere imkan tanıdığı için, marjinal taleplerin demokratik mücadelesi için uygun bir zemin hazırlamaktadır. Bu da marjinal grupla- rın yeraltına kaymalarına engel olur. Siyasal iktidarın etkileme ve denetlemeye katılımı oluşturan sivil toplum, demokrasi için güçlü bir altyapının temellerini atar(Erdoğan Tosun 2001: 181-182).

\subsection{Muhammed Raşid Gannuşi'nin Es- nek Siyasal Duruşu}

Raşid Gannuşi(1941 yılında Güney Tunus'taki el-Hamme kasabasında dünyaya geldi ve hala Tunus'ta yaşıyor), devlet erkinin idare 
edilmesinde istibdat ${ }^{11}$ konusu üzerinde hassasiyetle durmaktadır. Batı demokrasisinin iki temel ilkesi olduğunu söyler, bunlar: Meşruiyet(hukukilik) ve halkın egemenliği ilkesidir. Çağdaş batılılar, siyasi istibdattan kurtuluşun yeterli çözümünü söz konusu bu iki ilkede görmektedir. Ancak bu iki ilke ile siyasi istibdattın önüne geçilemiyor çünkü ahlaki boyutundan soyutlanmış siyasilerin firsatını bulduğu veya yasal düzenlemelerle istedikleri yasaları çıkarıp yolsuzluk yapabilmekteler(Gannuşi 2013: 293). Kanunilik, halk egemenliği, kuvvetler ayrılığı prensibi, basın özgürlüğü ve iktidarın el değiştirmesi gibi demokratik mekanizma ve ilkeler diktatör yönetim kurumlarının şiddet uygulamalarına bir sınır koymaktan aciz kalıyor(Gannuşi 2013: 294). Gannuşi'nin geçmiş tecrübeleri ve dünya literatürüne hâkim olması bu tespiti yapmaya götürmüştür. Sosyalist devlet ve batı açısından istibdattın kaçınılmaz olduğunu belirtmekle beraber aynı durumun İslam devletlerinde de olduğunu belirtiyor. Meşruiyetini her ne kadar İslam'ın Naslarından alsa da ilgili yönetici zamanla otoriter ve tartışılmaz kanun koyucu konumuna dönüşebilmektedir. İslam'ın devlet anlayışında, devlet bir sınıfın diğer bir sınıfı tasfiye etme yahut muhalif bir grubu şiddete gücü yetmiş olsa da ortadan kaldırmak için kullanılan bir araç değildir. Yine İslami tasavvura göre devlet, bir halkın, ırkın veya bir sınıfın onurunu yüceltmek uğruna diğer halkların ve ırkların aleyhine kullanılacak bir araç değildir. Devlet ancak bozuklukları ve yanlışlıkları düzeltmek, insan onurunu yüceltmek, temizlemek

\footnotetext{
${ }^{11}$ Uyruklarına hiçbir hak ve özgürlük tanımayan s1nırsız monarşi, despotluk, despotizm olarak tanımlanıyor TDK'de. http://www.tdk.gov.tr/in-
}

için bir araçtır(Gannuşi 2013: 293 - 294). Devlet konusunda net bir ifade kullanan Gannuşi siyasal anlamdaki düşüncelerini icraata da dökmüştür. Yasemin devrimi sonrası Tunus'ta istikrar ve Tunusluların maslahatına olacak şekilde siyasi manevralarda bulunmuştur.

Gannuşi, yasemin devrimi sonrası oluşan yönetimin devamlılığıyla birlikte eskiye dönüş şeklinde oluşabilecek distopik bir yönetimin olmaması adına, bazı siyasal tespitlerde bulunur. İslam devletlerinde de oluşabilecek istibdattın önüne geçmek için 5 ilkeden bahsetmektedir. Bunlar: Birinci ilke: Allah'ın yüce meşruiyeti ve halkın iktidarı denetlemesidir. İkinci ilke: İmamet bir sözleşme, imamların görevi burada halkın iradesinin gereğini yerine getirmek ve maslahatlarına riayet etmektir.(Tunus Anayasasinın 25. Maddesi Parlamenter milletvekili bütün ümmetin vekilidir). Üçüncü ilke: İnsanlara yakın olmak araya perde çekmemek ve onlardan uzaklaşmamak. Dördüncü ilke: Kuvvetler ayrılığı, bu da iki boyutludur a) Devlete düşen görevlerin üçe ayrılması, Yasama, Yürütme ve Yarg1; b) Bu vazifelerde görevli olan kurulların da birbirinden ayrılmasıdır. Beşinci ilke ise: Çok partililiktir(Gannuşi 2013: 294- 313). Gannuşi’ye göre bu ilkelerin yerine getirilmesi demokratik ve sürdürülebilir bir yönetim içim elzemdir.

Raşid Gannuşi bu perspektife nasıl ulaştı sorusunun cevabını bulmak için onun yaşadığı dönemdeki yöneticilerin tutumlarına bakmamız

dex.php?option=com gts\&ke-

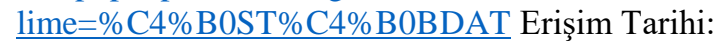
20.02.2018 
gerekecektir. Burgiba döneminde başlayan "İslami Yöneliş Hareketinin" ${ }^{12}$ önde gelen liderlerinden Raşid Gannuşi uzun süren mücadelelerin neticesinde Bin Ali zamanında İslami bir ismin siyasi parti adı olarak kullanılmama şartından dolayı İslami Yöneliş Hareketinin ismini Nahda Partisi olarak değiştirmiş ve 1987 de aktif olarak yönetime aday bir parti olarak varlığını göstermiştir. "Adını ve imajını değiştiren İslami hareket 1989 seçimlerine girmiş"(Okumuş 2015: 29) ve kısmi başarısı Bin Ali tarafindan kapatılmasına giden yolu açmıştır. Önde gelen yöneticilerinin tutuklanması bu döneme rast gelmektedir. Bu arada lider pozisyonundaki Raşid Gannuşi ise yurt dışına kaçmak zorunda kalmıştır. Siyasal anlamda tek partili bit yönetimle Tunus uzun süre yönetilmiştir. Devletin tüm kademelerinde bulunanlar ve Tunus'un ekonomisini elinde bulunduran elit kesimin laik ve seküler yaşam ve düşünüşüne yakın bir partinin yönetime gelmesi savunmuşlardır. $\mathrm{Bu}$ durum olası bir çatışmayı doğurabilirdi. Bu tutumun enNahda Partisi olarak "2014 yılında yapılan cumhurbaşkanlığ 1 seçimlerinde aday göstermediği gibi, herhangi bir aday destekleme konusunda resmi bir tutum belirlenmemiştir"(Okumuş 2015:49). Seçimlerde birinci çıkan Sibsi \%60 oy alarak cumhurbaşkanı olduktan sonra demokratik ilkelere bağlı ve İslami söylemlere karşı saygılı olacağını belirtmiştir.
Seçimlerden sonra Gannuşi ile yapılan bir röportajda şöyle bir ifade kullanmıştır: "Liderlerin yüzde 98 oy oranıyla seçildiği devirler geride kaldı.”(Okumuş 2015: 51).

Gannuşi’nin Tunus ve İslam dünyası açısından kayda değer düşünceleri birçok kişiyi heyecanlandırmıştır. Özelikle İslam'ın bir devlet formunun olmadığını esas olanın ise toplumun adalet ve refahını korumak olacağıdır. Bunu sağlayan ister laik yönetim olsun isterse dini bir yönetim olsun. $\mathrm{Bu}$ düşüncesinin eyleme geçişini Tunus'ta birinci parti olmasına rağmen iktidarı istikrar için bırakmasıyla ortaya koymuştur. Gannuşi bu durumu şöyle savunur: "Dinin birinci öncelliği devletin desteğini sağlamak değil, bireylerin kişisel katılımını sağlamaktır. Bizim İslam'1 empoze etmeye ihtiyacımız yok, çünkü İslam elitlerin dini değil, halkın dinidir. Uzun zaman boyunca İslam devlet desteğiyle değil insanların geniş ölçüde dini kabulü sayesinde var olmuştur. Bilakis devlet zaman zaman dine köstek olmuştur.”(Okumuş 2015: 32).

\section{Sonuç}

Tunus, bağımsızlığa kavuşmasında lider rol oynayan Burgiba'nın batı merkezli modernleşme düşüncesi çerçevesinde hareket etmiştir. Burgiba ve Bin Ali'nin yereli göz ardı eden politikaları Batı merkezli yaklaşımların yerelin gerçekleriyle karşı karşıya kaldıklarında yaşadıkları akıbeti gözleme fırsatı sunmuştur. "Gelişmenin Batıya göre yorumlanması ve Batılılar tarafından bu şekilde değerlendirilmesinin, ken-

birlikte İslami Yöneliş Hareketi'ni kuruyor(Oku- muş,2015,s:30).

\footnotetext{
${ }^{12}$ Raşid Gannuşi ile birlikte Abdulfettah Moro, Ahmida en-Nefir, Habib el-Mekni ve Salih Kurkur'un da aralarında bulunduğu yaklaşık 40 arkadaşıyla
} 
dileri açısından yararları olabilir. Fakat bu anlayış çerçevesindeki bilgiler evrensellik iddiasındaki açıklamalar olarak kabul edildiği zaman, toplumların sorun ve açmazları karşısında çözüm üretecek bilimsel çabaların, hangi bilim olursa olsun, tayin edilmiş bir çerçevesinin s1nırları dışına çıkamaması gibi durumla karşılaş1lır”(Tuna 2015: 50). Burgiba - Bin Ali deneyiminin akıbeti Arap baharı adıyla anılan sürecin ilk halkasını Tunus'taki "Yasemin Devrimi" teşkil etmiştir. Tunus'ta başlayan Arap Baharı domino etkisi ile birçok ülkeyi demokrasi ve özgürlük şiarlarını başat kabul eden çıkışlarla etkisi altına almıştır. Süreç, Mısır, Libya, Suriye, Bahreyn, Cezayir, Ürdün ve Yemen'de büyük çapta; Moritanya, Suudi Arabistan, Umman, Irak, Lübnan ve Fas'ta küçük çapta etki yaratmıştır(Polat 2015:107).

Tunus, süreci değişim ve yeni bir çerçevede inşa başarısıyla atlatan ülke olarak dikkati çeker. Ülkesinin problemli Ortadoğu coğrafyasında istikrar adası olarak kalabildiğini belirten Tunus cumhurbaşkanı Moncef Marzouki'nin El Cezire' de 5 Ekim 2014 tarihinde yayınlanan röportajındaki, “Arap Bahar'ının getirdiği değişiklikler Ortadoğu çevresinde hayal kırıklığı ve mezhepsel şiddet yüzünden giderek sorun olmaya devam ediyor. Ancak demokrasinin kök saldığı ve istikrarın görünen tek merkezi, Devrimin başladığı yer olan Tunus olarak görünüyor"13 ifadeleriyle, Tunus'un Arap Baharı sürecindeki özgün yerini işaret etmektedir.

\footnotetext{
${ }^{13} \mathrm{http}: / /$ www.aljazeera.com/programmes/talktojazeera/2014/10/moncef-marzouki-challenge-terrorism20141049337807102.html, Erişim tarihi: 05.01 .2018
}

“Arap Bahar'ının barışçıl ve çatışmasız bir şekilde geçiş yaptığı tek ülke Tunus olmuştur. Bunun arka planında, Arap Baharı sonrası Tunus'taki Nahda Hareketinin consensus ve demokratik çerçevede mücadele etmesi yatmaktadır."14 Ayrıca "Yasemin Devrimi” sonrası süreçte oluşan siyasal serbestlik ve STK' ların açı1ması ve faaliyeti önündeki yasal engellerin kaldırılması bir başka etkendir. Arap Baharı ile rejim değişikliği yoluna giden diğer ülkelerdeki başarısızlık Tunus deneyimini daha da önemli kılmaktadır. Gannuşi'nin liderlik kapasitesi, demokrasiyi derinleştiren siyasal çoğulculuğa izin verilmesi ve sivil toplum kuruluşlarının fonksiyonel çalışması Tunus'taki başarının unsurları olarak karşımızda durmaktadır.

Tunus halkını değişime yönelten motivasyonun ekonomik kaynağı açıktır. Hayat pahalılığı, işsizlik gibi halkın yaşamını doğrudan etkileyen faktörlerin etkisini göz ardı etmek mümkün değildir. Bununla birlikte, meselenin ekonomik çerçeveye sıkıştırılamayacağı, sokağa çıkan Tunusluların, “ekmek, eşitlik ve özgürlük” gibi bir sloganı sahiplenmesinden rahatlıkla anlaşılabilir. Dolayısıyla Tunus'taki "Yasemin Devrimini”, ekonomik sorunlar ve siyasal baskının şekillendirdiği ortama yönelik bir çıkış olarak değerlendirmek gerekir. Durkheim'in, toplumsal olguları asıl meydana getiren şey, topluluğun kolektif olarak ele alınan inançları, eğilim-

\footnotetext{
${ }^{14}$ https://www.stratejikortak.com/2015/12/arap-bahar-sonrasndaki-arap-ulkelerinin.html, Erişim tarihi: 05.01 .2018
} 
leri ve pratikleridir(Durkheim 1986: 42), belirlemesindeki bütünselliği dikkate alarak mesele ele alınmıştır.

Tunus'taki otoriter yönetimin, farklı söylemelere karşı gösterdiği tahammülsüzlük, sivil toplum kuruluşlarına ve alternatif siyasal partilere yönelik yasaklayıcı tutum, toplumu patlama noktasına getiren önemli faktörler arasındadır. Halkın yönetime dâhil olması ülke geleceğinde söz sahibi olması gibi demokratik hakların kısıtlanması ile birlikte dini ve sosyal baskının ayyuka çıktığı bir dönemde, Tunuslular için bir kıvılcım işlevi gören olaylar patlamıştır. Tunus'tan başlayarak birçok ülkeyi etkisi altına alan süreç, yalnızca Tunus'ta demokratik alt yapının kurulmasıyla neticelenmiş, diğer ülkelerde başarısızlığa uğramıştır.

Arap Baharı sürecini yaşamış diğer ülkelerin aksine, otoriter yönetim devrildiği, yerine demokratik usullerle istikrarlı bir yönetim kurulmuştur. Bu noktada ülkedeki İslamcı Nahda Partisinin liderliğini yürütmesi bakımdan kilit aktörler arasında yer alan Gannuşi’nin, demokrasi yönündeki 1srarı, uzlaşmaya açık tutumu önemlidir. "Liderlerin yüzde 98 oy oranıyla seçildiği devirler geride kaldı"(Okumuş 2015: 51) diyen Gannuşi dışlayıcı bir tutum yerine, seküler tarafla işbirliği içinde süreci inşa etmeye önem vermiştir. Gannuşi, istikrarsızlığa yol açacağı kaygısıyla, 2014 Cumhurbaşkanlığı seçimlerinde aday çıkarmayarak, laik, demokratik ve seküler bir parti olan Nidaa Tounes partisinin adayı Sibsi’nin önünü açmıştır. Seçimlerde birinci çıkan Sibsi \%60 oy alarak cumhurbaşkanı olabilmiştir. Tunus halkı için bu sonuç baskı ve hile ile elde edilen bir netice değildir. Aksine meşru bir seçimin meşru bir sonucudur. Haliyle kendi adayı seçilmeyen kişi dahi buna razı olmuştur.

Tunus'taki uzlaşma elbette bir takım tartışmalar çerçevesinde şekillenmiş bir sürecin sonucudur. Farklı kesimleri temsil eden sivil toplum kuruluşların aktif rolü, taleplerin yönetim kademesine ulaştırılmasında olumlu oynamıştır. “Özellikle Ağustos 2012'de yeni anayasanın yapımı aşamasında sorumlu komisyonun hazırladığı anayasa taslağında yer alan 28. Maddede kadın ve erkeğin birbirini "tamamlayıcı" olarak tanımlanması ülke içinde kadının konumu ile ilgili büyük bir tartışma başlatmıştır. Hak ve Özgürlükler alt komisyonunda görevli olan Nahda'nın bayan temsilcileri Feride Labidi ve Monia Brahim 28. Maddenin yanlış tercüme edildiğini ve bağlamı dışında kullanıldığını ifade etse de, bu tartışmaların yatışmasını sağlamamıştır. Binlerce Tunuslu gösteriler düzenleyerek çokeşlilik, resmi nikâh gibi haklarını kaybetme endişesi ile anayasa taslağına yönelik tepkilerini göstermiştir. 2014 yılı başında kabul edilen yeni anayasada yer alan 46. Maddedeki “ Devlet kadın hakları konusunda elde edilen kazanımları korumak, desteklemek ve geliştirmekle sorumludur" hükmüyle toplumdaki hassasiyet dikkate alınmıştır. (Journal Oficielle de la République Tunisienne, 20.04.2015; Dursun 2016:301). STK'ların "Yasemin Devrimi” sonrası somut etkilerini daha birçok örnekte görmek mümkündür.

Sivil toplum kuruluşları, çok partili hayat ve Gannuşi faktörlerinin olumlu katkısı Tunus'ta başarılı bir dönüşümü getirmiş ve istikrarlı bir 
demokrasinin geleceği için umut vadeden bir alt yapı sağlamıştır.

Gannuşi'nin yıllar önce kaleme aldığı “İslam Toplumunda Vatandaşlık Hakları" isimli eserinde dile getirdiği fikirler Tunus'taki dönüşüm esnasında sergilediği tutumunu dayanaklarını göstermektedir. Esas olanın dini bir devletten çok adaleti tesis eden bir devlet olduğunu savunan Gannuşi, "İlahi adalet, toplumsal zemin üzerinden ve insanc1l, hür, açı ve bütün inançları, mezhepleri ve görüşleri kendi gölgesinde yaşamaları için sahiplenen bir toplumun kurulması için yapılan çağrıda ortaya çıkar”(Gannuşi 1996: 73) ifadelerini kullanmıştır. Bu fikirlerle siyasal erkin kim olduğundan çok adaletli yönetim ihtiyacı vurgulanmıştır. Gannuşi, fikirlerini pratiğe geçirmek suretiyle, Tunus'ta olası İslamc1 - Seküler çatışmasının önüne geçmiş böylece, istikrarlı bir Tunus'un taşıııı sacayaklarından birisi belki de en önemlisi olmuştur.

Sonuç itibariyle Tunus'ta dönüşümü istikrarlı bir inşayla sürdürme imkânı yaratan sürecin ardındaki üç sacayağını, temsil ettikleri kesimlerin taleplerine sahip çıkan sivil toplum kuruluşları, serbest seçimlerle iktidara gelebilme hakkı çerçevesinde oluşmuş çok partili hayat ve demokrasi ile İslam'1 bir araya getiren Gannuşi’nin siyasal dehası olarak sıralayabiliriz. Tunus, Arap Baharı sürecindeki başarısız tecrübeleri değerlendirmek bakımından açıklayıcı veriler sunmakta, otoriter yönetimden demokratik yönetime dönüşümü kolaylaştıran unsuları anlamaya yardımcı olmaktadır.

\section{Kaynakça}

Albayrak, H. Şule (2018) ABD'de Din-Devlet İlişkileri, İz Yayıncılık, İstanbul

Altun, Fahrettin (2011) Modernleşme Kuramı Eleştirel Bir Giriş, Küre Yay. İstanbul

Arslantürk, Zeki ve Amman, Tayfun (2014) Sosyoloji Kavramlar, Kurumlar, Süreçler ve Teoriler, Çamlica Yay. İstanbul

Diamond, Larry (1994) Rethinking Civil Society: Tward Democratic Consolidation, Journal of Democracy, Cilt:5, No:3, July

Durkheim, Emile (1986) Sosyolojik Metodun Kuralları, Çev. Enver Aytekin, Sosyal Yay. İstanbul

Dursun, Hatice Rumeysa (2016) Otoriter Laiklikten Demokratik Laikliğe Türkiye ve Tunus'ta Din Devlet İlişkilerinin Dönüşümü, Doktora Tezi, Tez No: 454583, İstanbul

Erdoğan Tosun, Gülgün (2001) Demokratikleşme Perspektifinden Devlet - Sivil Toplum İlişkisi, Alfa Yay. İst.

Feldman, Noah (2013) İslam Devleti, Çev. İhsan Durdu, Ufuk Yay. İst.

Gannuşi, Muhammed el-Raşid (1987) İslami Yöneliş, Çev. Abdullah Baykal, Bir Yay. İst.

Gannuşi, Muhammed el-Raşid (1996) İslam Toplumunda Vatandaşlık Hakları, Çev. Abdulmecit Can, Birleşik Yay. İst.

Gannuşi, Muhammed el-Raşid (2016)Laiklik ve Sivil Toplum, Mana Yay. İst.

Gannuşi, Muhammed el-Raşid (2013) İslam Devletinde Kamusal Özgürlükler, Çev. Osman Tunç, Mana Yay. İstanbul

Giddens, Anthony (2000) Sosyoloji, Yayına Hazırlayan: Hüseyin Özel - Cemal Güzel, Ayraç Yay. Ankara

Köktaş, Rumeysa (2016)Tunus Politik Kültüründe Sivil Toplum: Tarihsel Bir Analiz, Ormer Perspektif Ser, Sakarya

Kenneth, Perkins (1986)Tunisia: Crossroads of the Islamic and European Worlds, Westview P.

Kenneth, Perkins (2014) A History of Modern Tunisia, Cambridge University Press, New York

Mardin, Şerif (1999) Siyasal ve Sosyal Bilimler, İletişim Yay. İstanbul

Okumuş, Fatih (2015) İslami Hareketin İktidar Deneyimi: Tunus ve misir, Mana Yay. İst.

Özdalga, Elisabeth (2009) Tarihsel Sosyoloji, DoğuBatı Yay. Ankara 
Polat, Ferihan ve Durmuş, Ayşegül (2015) İmmanuel Wallerstein Perspektifinde Arap Baharı Tunus Örneği, Çizgi Kitapevi, Konya

Sartori, Giovanni (1993) Demokrasi Teorisine Geri Dönüş, Çev. Tunçer Karamustafaoğlu ve Mehmet Turhan, Türk Demokrasi Vakfı, Ankara

Shain, Emad Eldin (1998)Political Ascent: Political Movement in North Africa, Westview Pres, USA

Tanriverdi, Nebahat (2011) Yaklaşan Seçim Öncesi Tunus'ta Siyasal Denklemler. Ortadoğu Analiz C. 3, S. 34, ORSAM, Ankara

Tuna, Korkut (2015)Batılı Bilginin Eleştirisi Üzerine, İz Yay. İstanbul

Turabi, Hasan (1998) İslam Dünyanın Geleceği, Çev. Esma Demirtaş, Birey Yay. İstanbul. 